\title{
Protein Synthesis-Dependent Memory and Neuronal Enhancement in Hermissenda Are Contingent on Parameters of Training and Retention
}

\author{
Rey R. Ramirez, Chetan C. Gandhi, Isabel A. Muzzio, and Louis D. Matzel ${ }^{1}$ \\ Program in Biopsychology and Behavioral Neuroscience \\ Department of Psychology \\ Rutgers University \\ New Brunswick, New Jersey 08903
}

\begin{abstract}
Following contiguous pairings of light and rotation, light alone elicits a conditioned contraction of Hermissenda's foot, indicative of an associative memory. After a 5-min retention interval, this conditioned response was evident following two or nine (but not one) conditioning trials but persisted for 90 min only after nine trials. In vivo incubation of animals in the protein synthesis inhibitor anisomycin (ANI; $1 \mu \mathrm{M})$ did not affect the conditioned response at the 5-min retention interval but significantly attenuated conditioned responding at the $90-\mathrm{min}$ interval even following nine training trials.

Deacetylanisomycin (DANI; $1 \mu \mathrm{M}$; an inactive form of anisomycin) had no effect on either 5- or 90-min retention. In a companion procedure, groups of isolated nervous systems were exposed to comparable light and rotation pairings, and the $B$ photoreceptors (considered a site of storage for the associative memory) underwent electrophysiological analysis. An increase in neuronal excitability (indexed by depolarizing voltage responses to injected current) in the B photoreceptors paralleled the expression of conditioned responding in intact animals, that is, two training trials produced a short-term increase in excitability that dissipated within $45 \mathrm{~min}$,
\end{abstract}

\footnotetext{
${ }^{1}$ Corresponding author.
}

whereas nine trials produced a persistent (at least 90-min) increase in excitability. In a final experiment, isolated nervous systems were exposed to nine training trials, and ANI or DANI was either present in the bathing medium before and during training or was introduced $5 \mathrm{~min}$ after training. Following training in ANI, a short-term (5to $45-\mathrm{min}$ ) but not persistent (90-min) increase in excitability in the $B$ photoreceptors was observed. ANI had no effect on either the short-term or persistent increase in excitability if the drug was applied $5 \mathrm{~min}$ after the last (ninth) training trial, and DANI had no effect on training-induced increases in excitability at any retention intervals. These results suggest that short-term retention in Hermissenda is protein synthesis indepedent but that new protein synthesis initiated during or shortly after the training event is necessary for even $\mathbf{9 0 - m i n}$ retention. Moreover, these results indicate that under some conditions, a critical threshold of training must be exceeded to initiate protein synthesis-dependent retention.

\section{Introduction}

The hypothesis that protein synthesis during or shortly after learning is necessary for the formation of long-term memory traces in both vertebrate and invertebrate brains has gained much acceptance in the past few decades. It has been observed repeatedly that protein or RNA synthesis inhibitors specifically block long-term memory but leave

LEARNING \& MEMORY 4:462-477 (C) 1998 by Cold Spring Harbor Laboratory Press ISSN1072-0502/98 \$5.00

$$
\begin{array}{lllllllllllllll}
L & E & A & R & N & I & N & G & \underset{462}{\mathbf{Z}} & M & E & M & O & R & Y
\end{array}
$$


short-term memory intact (e.g., Katz and Halstead 1950; Flexner et al. 1963; Davis and Squire 1984; Castellucci et al. 1989; Crow and Forrester 1990; Pedreira et al. 1996).

A number of studies have begun to elucidate the molecular pathways that underlie the induction of protein synthesis-dependent memory (Kaang et al. 1993; Frank and Greenberg 1994; Tully et al. 1994; Yin et al. 1994, 1995; Guzowski and McGaugh 1997). Compelling evidence suggests that the synthesis of proteins necessary for the formation of long-term memory is induced by training-dependent activation of multifunctional transcription factors (e.g., CREB isoforms; Stevens 1994; Alberini et al. 1995; Carew 1996; Tully 1997). Although less is known regarding the targets of these transcription factors, these proteins have been suggested to have many roles, such as gene regulation, synaptic growth and remodeling, proteolytic signaling, or self-perpetuating synthesis-dependent autophosphorylation (Alkon et al. 1990; Abraham et al. 1992; Bailey et al. 1992; Kaczmarek 1992; Lisman 1994, 1995; Spatz 1995; Osten et al. 1996).

One difficulty in assessing the targets of protein synthesis is that the data linking genetic modifications to behavior is often correlative in nature. For instance, in Drosopbila (where the functional significance of CREB has been most clearly implicated), intracellular recording from nervous system structures related to memory storage has been technically unfeasible. As a result, no synaptic or biophysical modifications of the neural network have been causally linked to behavioral changes following training (Tully et al. 1994; DeZazzo and Tully 1995; Yin et al. 1995). In rat, protein synthesis inhibitors block both in vitro long-lasting longterm potentiation (LTP) and long-term depression (LTD) (Huang et al. 1994; Nguyen et al. 1994; Linden 1996; Frey and Morris 1997), and long-term retention of several forms of learning (Davis and Squire 1984), but the link between these long-lasting forms of cellular plasticity and long-term behavioral retention is not entirely clear (cf. Llinas et al. 1997; Shors and Matzel 1997). Genetic manipulations in mice (i.e., gene targeting) and rats (i.e., antisense administration) have also helped link several molecules to long-lasting forms of neural and behavioral plasticity (Bourtchuladze et al. 1994; Abel et al. 1997; Guzowski and McGaugh 1997). But again, the details on how the electrophysiological and behavioral changes themselves connect are not well understood (Eichenbaum 1996).
With regards to the above limitations, molluscs have an important advantage. Because the cells in these animals are relatively large and often identifiable, behavioral modifications produced by training can (to some degree) be causally linked to biophysical and biochemical alterations in the nervous system. For instance, the marine mollusc Hermissenda exhibits a number of modifications of its behavioral responses to light (i.e., suppression of phototaxis and foot extension) following contiguous (associative) pairings of light and rotation (Crow and Alkon 1978; Lederhendler et al. 1986). These behavioral modifications have been causally related (Farley et al. 1983) or found to correlate closely (Matzel et al. 1992, 1996; West et al. 1982) with an enhancement of the excitability of B cells in the Hermissenda's eye, which is attributable to a decrease of both voltage- and calcium-dependent potassium currents (Alkon 1984; Alkon et al. 1985; Farley 1988).

Both short- and long-term retention of neuronal enhancement of the $B$ photoreceptors is mediated by a redistribution of protein kinase $C$ (PKC) from cytosolic to membrane components of the $B$ cell (McPhie et al. 1992; Muzzio et al. 1997) where the enzyme phosphorylates $\mathrm{K}^{+}$channels (Alkon et al. 1988). During conditioning, activation of PKC arises as a synergistic consequence of the combined actions of an intracellular $\mathrm{Ca}^{2+}$ rise (FalkVairant and Crow 1993; Matzel and Rogers 1993) concomitant with a release of lipid-derived activators of the kinase (Talk et al. 1997). Although these induction mechanisms have begun to be elucidated, the maintenance of neuronal facilitation beyond the duration of normal protein turnover is not well understood. Although long-term modifications of specific RNAs and phosphoproteins have been observed (e.g., Neary et al. 1981; Nelson and Akon 1988; Nelson et al. 1990; Crow et al. 1996), the mechanism by which these changes are induced have not been delineated and may occur independently of new protein synthesis. However, one series of experiments has suggested a role for protein synthesis in the retention of neuronal facilitation in Hermissenda. Crow and Forrester (1990) reported that the inhibition of translation during (but not after) a pairing of light and the facilitatory transmitter 5-HT blocks long-term (24 hr) but not short-term neuronal facilitation (as indexed by an enhancement of the light-induced generator potential). Although suggestive, these results do not directly address the role of protein synthesis in behavioral retention or in the neuronal

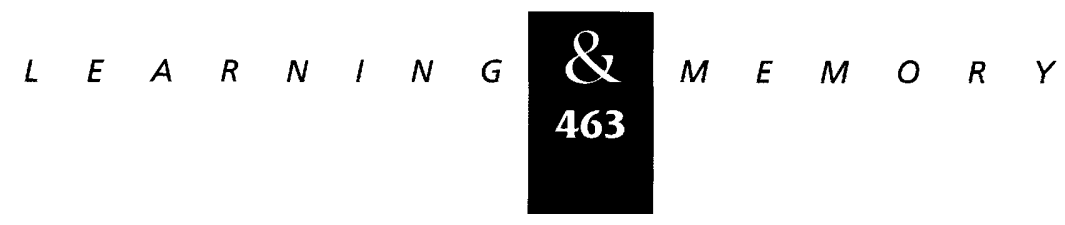


Ramirez et al.

facilitation that accompanies pairings of light and presynaptic hair cell stimulation. Surprisingly, as of yet, there have been no invertebrate studies of protein synthesis-dependent long-term associative memory that have included both behavioral and electrophysiological measures. In the present experiments we examined the role of protein synthesis in both of these processes. Our results indicate that at both the behavioral and biophysical levels, persistent memory is protein synthesis dependent, whereas memory induction and short-term expression is protein synthesis independent. Moreover, we have determined that a minimum of more than two paired trials is necessary for the induction of the protein synthesis-dependent long-term memory, suggesting that the extent of training interacts with nuclear regulation to establish a persistent memory trace.

\section{Materials and Methods}

\section{SUBJECTS}

Adult Hermissenda were obtained from Sea Life Supply (Sand City, CA) and were confined individually in perforated tubes in $12^{\circ} \mathrm{C}$ artificial seawater (ASW). Animals were maintained on a 10- to 14-hr light-dark cycle and were fed a portion of Hikari Gold fish food $1 \mathrm{hr}$ before the dark cycle on alternating days. The dim maintenance light was filtered through yellow acetate and had an intensity at the surface of the water of $3 \mathrm{fc}$. All Hermissenda were given a minimum of 3 days to acclimate before any behavioral testing. Experimental manipulations were conducted during the middle $8 \mathrm{hr}$ of the light cycle.

\section{APPARATUS}

Animals were confined to a track $(15 \times 0.9 \times$ $0.6 \mathrm{~cm} ; \mathrm{L} \times \mathrm{W} \times \mathrm{H})$ filled with $12^{\circ} \mathrm{C}$ ASW. Six such tracks were milled into a sheet of clear Plexiglas. An opaque white Plexiglas cover could be clamped over the field of tracks, thereby isolating the individual tracks. The Plexiglas sheet was mounted on a Lab Line Shaker (model 4600), which when operated produced an orbital rotation of $300 \mathrm{rpm}$, with $4 \mathrm{~mm}$ of total displacement. This rotation served as the unconditioned stimulus (US). Sixty centimeters above the track was a $40-\mathrm{W}$ (at $130 \mathrm{~V}$ ) light that served as the conditioned stimulus (CS). This light illuminated the field of tracks with a uniform intensity of $50 \mathrm{fc}$. The shaker was housed in a sound- and light-proof incubator that maintained a temperature of $12^{\circ} \mathrm{C}$. Behavioral responses were recorded with a CCD video camera (Sony AVC-D7,

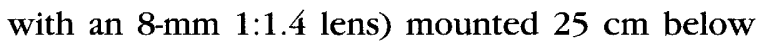
the track.

\section{IN VIVO CONDITIONING PROCEDURE (EXPERIMENT 1)}

In our first experiment we determined the minimum number of training trials necessary for the establishment of a conditioned response that persisted for periods of time longer than could reasonably be accommodated by a single phosphorylation event. Animals were randomly assigned to groups with the restriction that the size of individual animals was matched across conditions. Before conditioning, animals were placed in the Plexiglas tracks for $10 \mathrm{~min}$ in the darkened training incubator. Paired training consisted of a 5-sec light, followed by $4 \mathrm{sec}$ of rotation with a 1-sec interstimulus interval. Each of the pairings occurred at 60-sec intertrial intervals, and unpaired presentations of light and rotation were identical except that $30 \mathrm{sec}$ intervened between the light and rotation. Groups of animals were trained with either no (naive), one, two, or nine paired (conditioned) or unpaired (control) presentations of light (CS) and orbital rotation (US), and half of the animals were tested $5 \mathrm{~min}$ after the last light presentation, whereas half were tested $90 \mathrm{~min}$ after the last light presentation (or at a comparable time point for naive animals). Thus, 14 groups were represented in this experiment; naive animals tested at $5 \mathrm{~min}$ or $90 \mathrm{~min}$, animals trained with one, two, or nine pairings tested at $5 \mathrm{~min}$ or $90 \mathrm{~min}$, and animals trained with one, two, or nine unpaired presentations tested at $5 \mathrm{~min}$ or $90 \mathrm{~min}$. Testing consisted of the presentation of a 10-sec light during which the animal's response was videotaped. The length of the animal's foot was measured $50 \mathrm{msec}$ after light onset and again $50 \mathrm{msec}$ before the offset of the light. Only animals that were not turning or at the end of a track during the test light contributed to the data set. The experiment was conducted in two replications (of either the 5- or 90-min retention group), and each replication contained 6 animals from each of the above groups, for a total of 12 animals per group.

\section{MEASUREMENT OF PROTEIN SYNTHESIS INHIBITION}

It has been reported previously that $60 \mathrm{~min}$ of

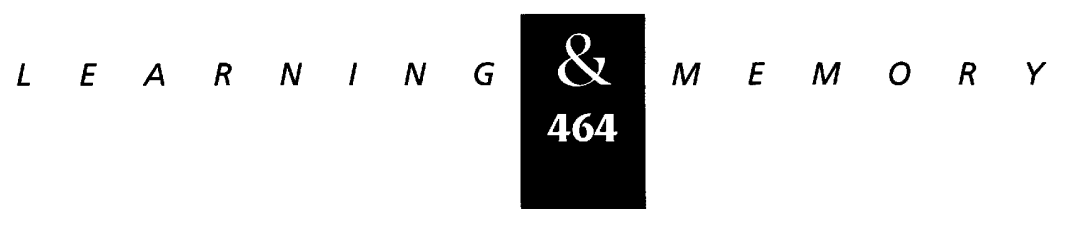


incubation of the exposed Hermissenda nervous system in anisomycin (ANI; $1 \mu \mathrm{M}$ ) induces an 86\% reduction in the incorporation of $\left[{ }^{3} \mathrm{H}\right]$ leucine. In contrast, the inactive derivative of ANI, Deacetylanisomycin (DANI; $1 \mu \mathrm{M}$ ), induced only a $3 \%$ reduction in leucine incorporation (Crow and Forrester 1990). The same concentration of ANI (and DANI) was used in the present studies where the drug was bath-applied to exposed (excised) nervous systems (experiment 4), as well as in an in vivo experiment where ANI (or DANI) was administered by introduction of the drug into the seawater bath of the intact animal (experiment 2). Although the circumesophageal nervous system of Hermissenda is in relatively unrestricted contact with the seawater environment, it was necessary to determine the effectiveness of ANI in the intact animal following this novel route of administration. To determine the extent of protein synthesis inhibition in the Hermissenda nervous system induced by bath application of ANI, the intact animal was maintained in seawater containing ANI (or control solutions), the animals' nervous systems were excised, and leucine incorporation into protein insoluble trichloracetic acid (TCA) was assessed. Groups of 10 animals were placed in a $2000-\mathrm{ml}$ ASW bath $\left(12^{\circ} \mathrm{C}\right)$ to which either ANI $(1 \mu \mathrm{M})$, DANI $(1 \mu \mathrm{M})$, or nothing was added. Following $70 \mathrm{~min}$ in these baths, animals were removed and rinsed in normal ASW, and their nervous systems were excised. The pooled nervous systems from each of the three groups were transferred to glass homogenization tubes where they were incubated at room temperature $\left(20^{\circ} \mathrm{C}, 40 \mathrm{~min}\right)$ in ASW containing $150 \mu \mathrm{Ci} / \mathrm{ml}$ of $\left[{ }^{3} \mathrm{H}\right]$ leucine (American Radiolabeled Chemicals). Nervous systems were then washed three times in ice-cold phosphate-buffered saline, and the third wash $(1 \mathrm{ml})$ was adjusted to $10 \%$ (wt/vol) TCA. Nervous systems were then homogenized in $1 \mathrm{ml}$ of the TCA solution, incubated on ice for $30 \mathrm{~min}$, transferred to chilled centrifuge vials, and spun at $10,000 \mathrm{~g}$ for $10 \mathrm{~min}$, after which the pellets were washed and resuspended in ice-cold 10\% TCA. Centrifugation and suspension were repeated for two additional cycles, and the final suspension was filtered under vacuum through Whatman GF/C glass filter papers $(2.5 \mathrm{~cm}$, no. 1822025). The filters were transferred th scintillation vials containing $3.0 \mathrm{ml}$ of scintillation liquid (ScintiVerse; Fisher). Radioactivities were quantified by scintillation counts obtained in triplicate from each of eight vials (two each of ANI, DANI, ASW, and blank), and the average value was computed for each condition. Blank values were subtracted from each of the three treatment values. Relative to the nervous systems of animals incubated in normal ASW, $\left[{ }^{3} \mathrm{H}\right]$ leucine incorporation was inhibited by $69 \%$ following in vivo ANI incubation and $1 \%$ following similar incubation in DANI. Thus, as with application of ANI to the exposed nervous system (Crow and Forrester 1990), incubation of intact Hermissenda in a bath containing ANI effectively impairs new protein synthesis.

\section{EFFECTS OF IN VIVO PROTEIN SYNTHESIS INHIBITION ON UNCONDITIONED RESPONSES}

To determine whether in vivo exposure to the protein synthesis inhibitor ANI affected normal responsivity to sensory stimulation used in our conditioning procedures, the responses of animals to light and rotation following ANI incubation were compared with animals incubated in normal seawater. Animals were incubated in either ANI or ASW according to the protocol described above. At the end of the 70-min exposure, the bathing solutions of both groups were replaced with fresh ASW, and the animal's unconditioned responses to light and rotation were assessed after 5 and $90 \mathrm{~min}$. During this 90-min interval, animals were maintained in darkness except during a 10-sec test light (at 5 and $90 \mathrm{~min}$ ) or during a 5 -sec period of dim red light (to allow visualization) that began $5 \mathrm{sec}$ before a 4 -sec period of rotation that occurred 60 sec after each test light. The responses of the animals to the test lights and rotation were videotaped. For each animal, phototaxis and foot extension were measured during the test light (from $\mathbf{5 0}$ msec after onset until $50 \mathrm{msec}$ before offset of light), and foot contraction was measured during the period of rotation.

During the 10-sec test light, animals incubated in ASW locomoted on average $10.6 \mathrm{~mm}$ and $\mathbf{1 2 . 8}$ $\mathrm{mm}$ at the 5- and 90-min tests (respectively), whereas animals incubated in ANI locomoted 11.8 $\mathrm{mm}$ and $13.2 \mathrm{~mm}$ during the same tests. Animals incubated in ASW exhibited a 3.5\% increase in foot length at $5 \mathrm{~min}$ and a $4.3 \%$ increase at $90 \mathrm{~min}$. Those incubated in ANI exhibited similar increases of $3.0 \%(5 \mathrm{~min})$ and $4.1 \%(90 \mathrm{~min})$. None of these nominal between-group differences in unconditioned responding to light approached significance at either time point $[F \mathrm{~s}(1,39) \leqslant 1.22$, not significant (NS)].

During the 4-sec period of rotation, animals incubated in ASW exhibited an average foot con-

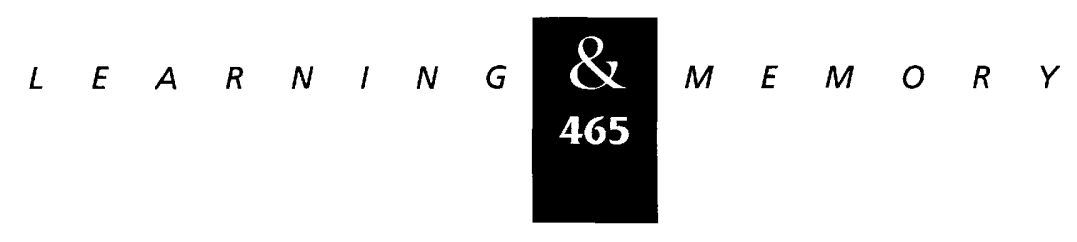


traction of $8.2 \%$ at $5 \mathrm{~min}$ and $7.3 \%$ at $90 \mathrm{~min}$. Animals incubated in ANI exhibited a $7.1 \%$ and $8.5 \%$ contraction during the same tests. None of the differences between groups approached significance $[F \mathrm{~s}(1,39)=0.79, \mathrm{NS}]$.

In addition to the measures of unconditioned responding described above, it should be noted that no obvious differences in the behavior or appearance of the animals incubated in ANI were detected. Moreover, ANI did not have any discernable effect on the peak light response or resting membrane potential of the B photoreceptors relative to either ASW or DANI (experiment 4; Fig. 4, below). On the basis of these combined results, it appears that in vivo exposure to ANI $(1 \mu \mathrm{M})$ did not induce abnormalities in the response to stimuli used in our in vivo (experiment 2) or in vitro (experiment 4) conditioning procedures.

\section{EFFECTS OF IN VIVO PROTEIN SYNTHESIS} INHIBITION ON RETENTION (EXPERIMENT 2)

Animals were treated and trained in a manner similar to the prior description. Two groups of animals were trained in a normal bathing medium (ASW) and received either nine paired or nine unpaired trials and were tested at either 5 min or 90 min after the last training light (groups P-ASW:5, UP-ASW:5, P-ASW:90, and UP-ASW:90). Two additional groups of animals received paired training in the presence of ANI that was added to the ASW bath $70 \mathrm{~min}$ before the first training trial and were tested after either $5 \mathrm{~min}$ or $90 \mathrm{~min}$ of retention (groups P-ANI:5 and P-ANI:90). To control for nonspecific effects of ANI, two additional groups were trained and tested in the same manner except that an inactive form of ANI (DANI) replaced ANI in their bathing medium (groups P-DANI:5 and PDANI:90). Incubation in either ASW, ANI, or DANI was begun $60 \mathrm{~min}$ before training by placing animals in plastic containers filled with 4 liters of either ASW, ASW supplemented with ANI ( $1 \mu \mathrm{M})$, or DANI $(1 \mu \mathrm{M})$. Following incubation, animals were placed in the Plexiglas tracks filled with the same incubation solution for $10 \mathrm{~min}$ in the darkened training incubator, at which time training was begun. The bathing medium of animals tested at the 90-min retention interval was exchanged with ASW 5 min after the end of training and again 32 min and 77 min after training. The bathing medium of animals tested at the 5-min retention interval was not exchanged before testing. Testing was conducted as in the prior description. This experi- ment was conducted in four replications, each with six animals per group.

\section{IN VITRO ELECTROPHYSIOLOGY (EXPERIMENT 3)}

Previous work (Matzel et al. 1990a) has indicated that the B photoreceptors of the Hermissenda eye undergo an increase in excitability (facilitation) following exposure of the isolated nervous system (containing an intact visual-vestibular network) to pairings of light and rotation. In the present experiment, isolated nervous systems were trained with no (naive), one, two, or nine paired or unpaired presentations of light and rotation, and excitability of the $\mathrm{B}$ photoreceptor (indexed by the voltage response to injected current) was assessed 5, 45, and 90 min after the final training event. Our intent was to assess the acquisition and decay of neuronal facilitation using training conditions similar to those of the previous behavioral experiments.

Five groups of nervous systems (six to eight per group) received in vitro conditioning in this experiment. The nervous systems of the animals were surgically isolated, pinned to strips of grease on a glass slide, enzymed (Sigma XXIV; $2 \mathrm{mg} / \mathrm{ml}$ of ASW) for $5 \mathrm{~min}$ at $22^{\circ} \mathrm{C}$, and rinsed in $14^{\circ} \mathrm{C} \mathrm{ASW}$. Each nervous system was placed in an ASW (supplemented with $40 \mathrm{~mm}$ glucose) filled dish in a darkened incubator for 20 min during which either no stimuli were presented (naive) or one, two, or nine pairings of light and rotation were presented. The fifth group of nervous systems received nine unpaired presentations of light and rotation (as any nonassociative effects of training would be greatest in the comparable paired condition). Trial spacing was as in the prior behavioral experiments, and the last stimulus presentation occurred $30 \mathrm{sec}$ before the end of the session for all groups. In this manner, all nervous systems spent $20 \mathrm{~min}$ in the incubator regardless of the number of training trials. Thirty seconds after the final stimulus presentation, each nervous system was placed in a dark container and transferred to an electrophysiology stage, and a B cell was impaled with a 40- to 50-M $\Omega$ (KAc filled) microelectrode. Five minutes after removal from the incubator, membrane potential was recorded, and a positive current pulse $(+0.8$ nA, $500 \mathrm{msec}$ ) was passed through a balancedbridge circuit to measure membrane voltage responses. Any preparation from which data were not collected within $5 \mathrm{~min}$ of removal from the incubator was discarded. All tests were repeated at

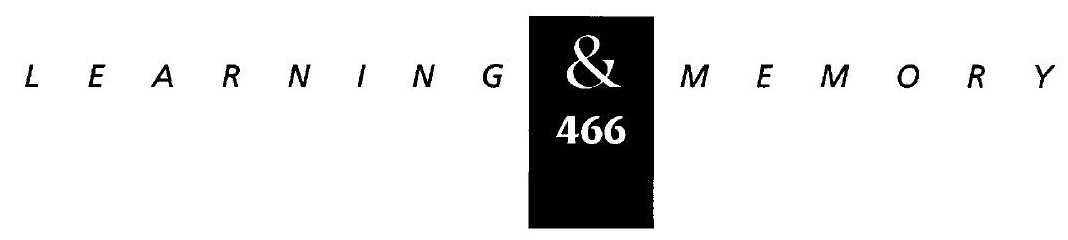


$45 \mathrm{~min}$ and $90 \mathrm{~min}$ after the end of the training session. Throughout the experiment, nervous systems were continually perfused with ASW supplemented with glucose $(0.1 \mathrm{ml} / \mathrm{min}$ through the 0.2 $\mathrm{ml}$ recording chamber).

\section{IN VITRO PROTEIN SYNTHESIS INHIBITION (EXPERIMENT 4)}

In the prior experiments, it was determined that nine training trials produced behavioral retention and neuronal facilitation that persisted for 90 min, whereas one or two training trials had only transitory effects. In the present experiment, we asked whether the neuronal facilitation observed 90 min after the final training trial was affected by inhibition of protein synthesis initiated before the start or after the completion of training. Isolated nervous systems were trained with nine paired or unpaired presentations of light and rotation as in the previous experiment, except that the nervous systems were incubated in ASW, ANI, or DANI either before (and throughout) or after training.

The nervous systems were prepared as in the prior experiment, except that they received an additional $60 \mathrm{~min}$ in the darkened training incubator before training during which they were bathed in either ASW, ANI, or DANI. Training and testing conditions were as described for the previous experiment, except that all nervous systems received nine paired or unpaired training trials. These two types of training were administered in one of three bathing solutions, that is, normal ASW or ASW supplemented with ANI ( $1 \mu \mathrm{M})$ or DANI ( $1 \mu \mathrm{M})$. The two drug conditions were further subdivided into groups receiving drug administration throughout training and the preceding $70 \mathrm{~min}$ (i.e., "before" training) or administration beginning $5 \mathrm{~min}$ after the final training event (i.e., "after' training). In those nervous systems exposed to ANI or DANI before and during training, washout of the drugs began immediately after the 5-min retention test. For those exposed to ANI or DANI after training, washout of the drugs began after 70 min of exposure. In all cases, nervous systems were continuously perfused with their respective incubation solution throughout the experiment at $\sim 0.1 \mathrm{ml} / \mathrm{min}$.

In total, 10 groups of nervous systems (six nervous systems per group) were trained in this experiment: Paired in ASW (P-ASW), unpaired in ASW (UP-ASW), paired with ANI before training (PANI:B), unpaired with ANI before training (UP-
ANI:B), paired with ANI after training (P-ANI:A), unpaired with ANI after training (UP-ANI:A), paired with DANI before training (P-DANI:B), unpaired with DANI before training (UP-DANI:B), paired with DANI after training (P-DANI:A), and unpaired with DANI after training (UP-DANI:A). Excitability of the B cell was assessed 5, 45, and $90 \mathrm{~min}$ after the final training event, and in this experiment both depolarizing voltage responses to injected current and evoked spike rate data were recorded.

\section{STATISTICAL ANALYSIS}

Between-groups analyses of variance (ANOVAs) were conducted on all data. Comparisons of individual group means and within-group comparisons as a function of retention interval were made with planned comparisons based on the error term from the ANOVA.

In all experiments, data was obtained by an experimenter that was unaware of the treatment history of the animals.

\section{Results}

MORE THAN TWO PAIRED TRIALS ARE NECESSARY FOR PERSISTENT RETENTION

The results of behavioral testing after no (naive), one, two, or nine paired or unpaired presentations of light and rotation are depicted in Figure 1. Because animals tested at the 5-min retention interval and those tested at the 90-min interval were trained in separate replications, separate analyses were conducted on the data acquired at each of these retention intervals. Five minutes following the end of the training session, animals that received one, two, or nine paired trials all exhibited a net foot contraction during the 10-sec test light as is apparent in the top panel of Figure 1. Animals that received one, two, or nine unpaired trials and naive animals exhibited a net foot extension to the same test light. ANOVA indicated a significant difference between groups at the 5-min retention interval, $[F(6,71)=4.75, P<0.001]$. Although a net contraction was observed in animals that received paired training with one, two, or nine trials, the contraction differed from the foot extension exhibited by unpaired animals only after two or nine paired presentations. Each of these paired groups (two or nine trials) differed from their

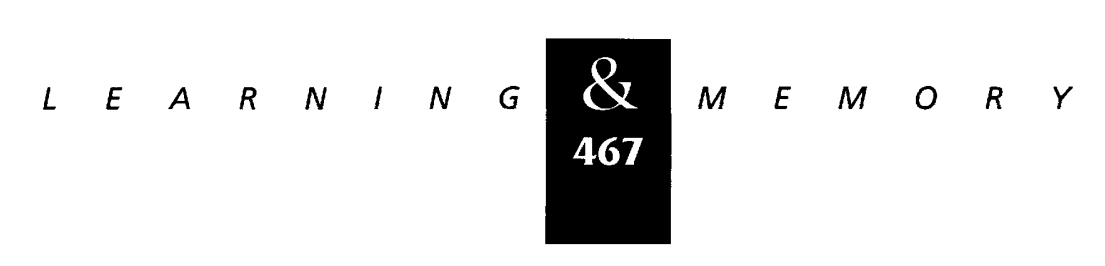



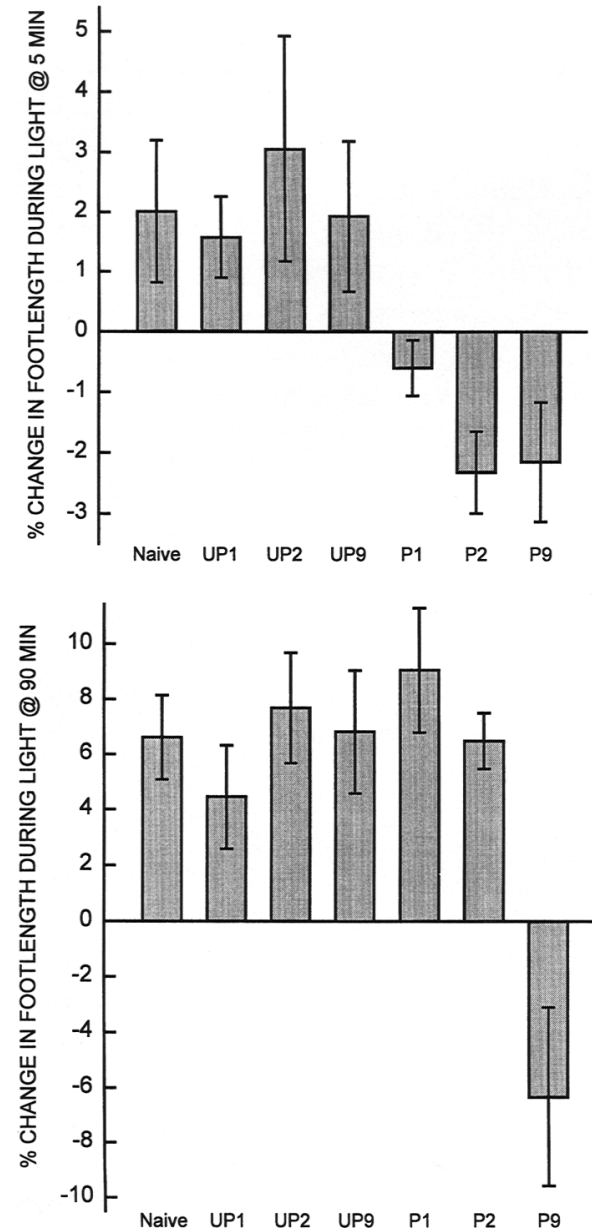

Figure 1: Effects of degree of training on the retention of a conditioned foot contraction. Seven groups of intact animals received either no (naive), one, two, or nine paired (conditioned) or unpaired (control) presentations of light (CS) and orbital rotation (US), and they were tested at retention intervals of $5 \mathrm{~min}$ or $90 \mathrm{~min}$. The development of a clinging response, characterized by the contraction of the animal's foot, was used as index of learning and was quantified by measuring the percent change in foot length at the light offset relative to the premeasure at light onset. (Top) The groups receiving paired training exhibited a foot contraction at a retention interval of $5 \mathrm{~min}$. The naive and the unpaired groups exhibited foot extensions. Brackets indicate S.E. (Bottom) Only the group that received nine paired trials exhibited a foot contraction at a retention interval of $90 \mathrm{~min}$. The naive, the unpaired, and the paired groups receiving one or two trials exhibited a foot extension at a retention interval of $90 \mathrm{~min}$. Brackets indicate S.E.

respective unpaired control group as well as from the naive control group $[F \mathrm{~s}(1,71) \geqslant 7.90$, $P s<0.05]$ but did not differ from each other. This result suggests that two training trials are sufficient for asymptotic learning when assessed at this short retention interval. In contrast, animals trained with a single paired trial exhibited a net foot contraction but did not differ significantly from their unpaired control $[F(1,71)=1.65$, NS $]$.

Groups differed significantly from each other at the 90 min retention interval $[F(6,55)=6.09$, $P<0.001$ ]. Visual inspection of the $90-\mathrm{min}$ retention data in the bottom panel of Figure 1 suggests a different pattern of responding than was evident in the 5-min retention test (top panel). In contrast to the 5-min test, only animals trained with nine pairings of light and rotation exhibited a foot contraction at the $90-$ min retention interval. Animals trained with nine pairings differed significantly from the one- and two-trial paired groups $[\mathrm{Fs}$ $(1,55) \geqslant 13.92, P s<0.01]$, as well as from their unpaired control and the naive control group $[F \mathrm{~s}(1,55) \geqslant 14.2, P \mathrm{~s}<0.01]$. Animals trained with one or two paired trials did not differ from each other, from their unpaired control groups, or from the naive control group $[F \mathrm{~s}(1,55) \leqslant 1.29$, NS]. These results suggest that although a 5-min retention of the conditioned foot response is obtainable with two or nine pairings of light and rotation, more than two paired presentations are necessary for 90 -min retention.

\section{PERSISTENT RETENTION IS PROTEIN SYNTHESIS DEPENDENT}

In experiment 2, animals received behavioral training with nine trials following in vivo incubation in either ASW, ASW supplemented with ANI, or DANI. Following paired or unpaired training, these animals were tested for retention either 5 min or $90 \mathrm{~min}$ after training, and the results are presented in Figure 2. ANOVA revealed a significant difference between groups $[F(7,68)=9.15$, $P<0.0001]$. Five minutes after the end of the behavioral training session, the groups of animals that received paired training all exhibited a net foot contraction. The three paired groups tested at the 5-min retention interval did not differ from one another $[F s(1,68) \leqslant 0.88, N S]$, but all differed from the unpaired control group $[F s(1,68) \geqslant 14.86$, $P$ s $<0.01]$. This result indicates that there was no nonspecific effect of the two drugs (ANI and DANI) on the capacity to learn or to generate a conditioned response.

Animals tested after the 90-min retention interval displayed a different pattern of responding. Groups trained after incubation in ASW or DANI displayed comparable foot contractions indicative

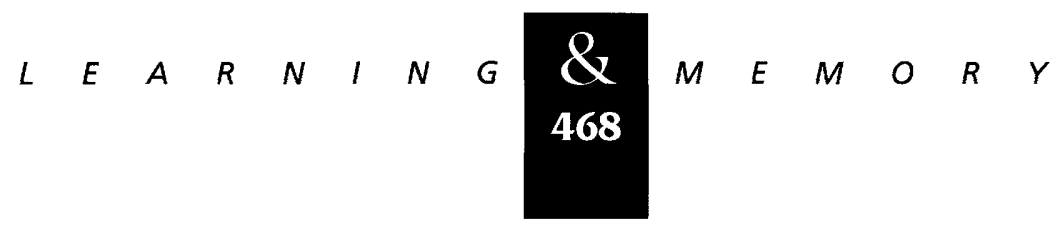




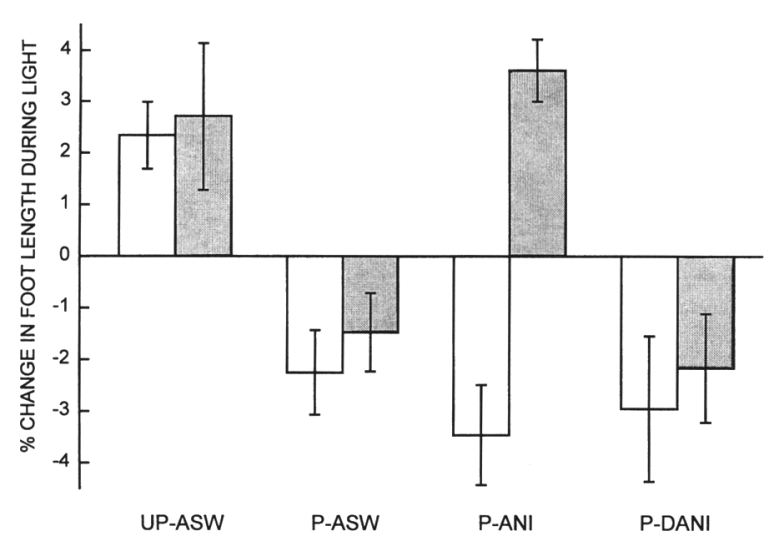

Figure 2: Effect of protein synthesis inhibition on shortand long-term retention of a conditioned foot contraction. Eight groups of animals were incubated in vivo in ASW, ANI, or DANI before training, which consisted of nine trials of light and rotation under paired (ASW, ANI, and DANI groups) or explicitly unpaired conditions (ASW only). Following training, animals were tested at retention intervals of $5 \mathrm{~min}$ (open bars) or $90 \mathrm{~min}$ (shaded bars). The development of a clinging response, characterized by the contraction of the animal's foot, was used as index of learning and was quantified by measuring the percent change in foot length at the light offset relative to the premeasure at light onset. The paired ASW groups and the paired DANI groups exhibit a foot contraction at retention intervals of 5 and $90 \mathrm{~min}$. The paired ANI groups exhibited a foot contraction at 5 $\mathrm{min}$ but at $90 \mathrm{~min}$ exhibited a foot extension. The ASW unpaired controls exhibited a foot extension at both 5 and $90 \mathrm{~min}$ after training. Brackets indicate S.E.

of retention, and both differed from the unpaired control group at $90 \mathrm{~min}[F \mathrm{~s}(1,68) \geqslant 6.13, P \mathrm{~s}<0.05]$. However, the group trained after incubation in ANI exhibited no retention, that is, they did not differ from the unpaired control animals $[F s(1,68)=$ $0.54, N S]$. These results suggest that 5 -min retention is independent of protein synthesis, whereas 90-min retention is protein synthesis dependent. This conclusion is strengthened by the observation of comparable $5 \mathrm{~min}$ and $90 \mathrm{~min}$ retention following incubation in DANI, the inactive form of ANI.

\section{MORE THAN TWO PAIRED TRIALS ARE NECESSARY FOR PERSISTENT ENHANCEMENT OF B-CELL EXCITABILITY}

The depolarizing voltage response to constant current injection (a measure of excitability) of $B$ photoreceptors was measured 5, 45, and $90 \mathrm{~min}$ (in the same cells) after the end of in vitro training sessions in which isolated nervous systems received no stimulus presentations (naive), one, two, or nine paired trials, or nine unpaired trials. The mean voltage responses to constant current injection are displayed in Figure 3. Two training trials produced a short-term increase in neuronal excitability that dissipated within $45 \mathrm{~min}$, whereas nine paired trials produced a persistent (at least 90-min) increase in excitability. A two-factor ANOVA indicated a significant effect of type of training $[F(4,119)=5.10, P<0.01]$, a significant effect of retention interval $[F(2,119)=5.06, P<0.01]$, and a significant interaction between type of training and retention interval $[F(8,119)=5.24, P<0.001]$. Comparison of individual mean scores indicated that nine unpaired trials produced no increase in

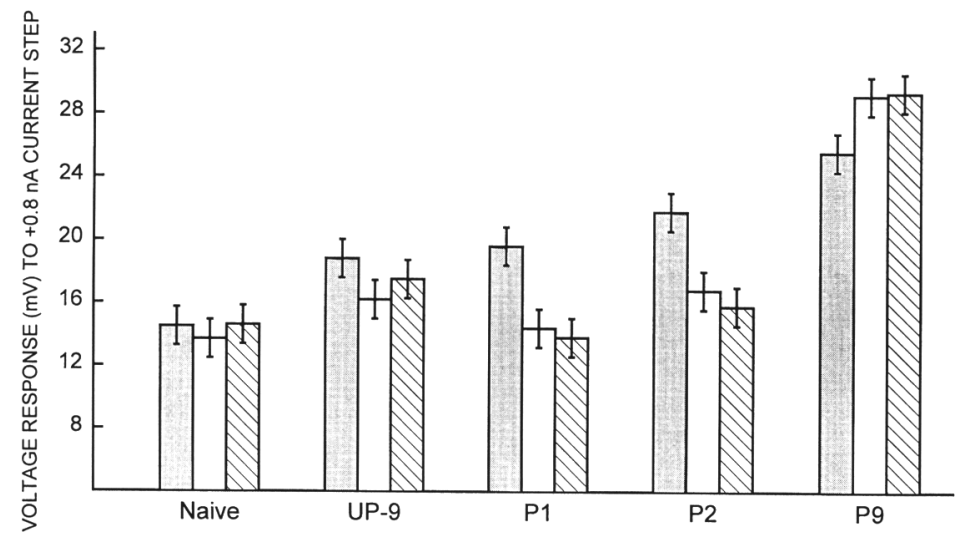

\begin{tabular}{llllllllllllllll}
\hline & $A$ & $R$ & $N$ & $I$ & $N$ & $G$ & $\bigotimes_{469}$ & $M$ & $E$ & $M$ & $O$ & $R$ & $Y$
\end{tabular}
Figure 3: Effect of degree of training on retention of B-cell excitability enhancement. Isolated nervous systems were trained with either no (naive), one, two, or nine paired (conditioned) or nine unpaired (control) presentations of light (CS) and orbital rotation (US). The depolarizing voltage response of the $B$ cell was measured with $+0.8-n A$ current injections at 5 (shaded bars), 45 (open bars), and 90 (hatched bars) min after training. B-cell voltage responses of groups receiving one or two paired training trials were elevated at $5 \mathrm{~min}$ but dissipated within $45 \mathrm{~min}$, whereas the depolarizing voltage response of the group receiving nine paired trials continued to be elevated even at $90 \mathrm{~min}$. The naive and the unpaired groups exhibited relatively small depolarizing voltage responses at $5 \mathrm{~min}$, which remained unchanged at $45 \mathrm{~min}$ and $90 \mathrm{~min}$. Brackets indicate S.E. 
excitability relative to the naive control group either 5,45 , or $90 \mathrm{~min}$ after the end of the training session $[F \mathrm{~s}(1,119) \leqslant 1.51$, NS $]$. At the 5-min retention interval, paired training with two or nine trials produced an increase in the voltage response to injected current relative to the naive control condition $[F \mathrm{~s}(1,119) \geqslant 4.35, \quad P \mathrm{~s}<0.05]$, and nine paired training trials produced an increase relative to nine unpaired trials $[F(1,119)=7.70, P<0.01]$. Although one training trial induced a tendency toward an increase in the voltage response, this difference did not reach statistical significance $[F(1,119)=2.55$, NS $]$.

At the 90-min retention interval, B cells from nervous systems that received nine paired trials displayed a greater depolarizing voltage response than did those from nervous systems that received nine unpaired trials $[F(1,119)=12.35, P<0.01]$. Moreover, at the 90-min interval, nervous systems that received nine paired trials differed from those that received one or two paired trials $[F \mathrm{~s}(1,119) \geqslant$ $16.12, P \mathrm{~s}<0.001]$, and this difference was attributable at least in part to a decrease in the excitability of the B cell throughout the retention interval in those groups trained with one or two pairings of light and rotation. In total, these results indicate that more than two trials are necessary for the persistent increase in cell excitability that is observed 90 min after training.

PERSISTENT ENHANCEMENT OF B-CELL EXCITABILITY IS PROTEIN SYNTHESIS DEPENDENT

In this experiment we examined whether the sustained increase in excitability following nine in vitro training trials was dependent on protein synthesis during or after the conclusion of training. Both depolarizing voltage responses and evoked spike rates were assessed 5, 45, and $90 \mathrm{~min}$ after the completion of training in paired and unpaired groups of animals trained in ASW or ASW supplemented with ANI or ASW supplemented with DANI. Before examining the effects of these drugs on training-induced enhancement of excitability, we examined the effects of ANI and DANI on basal electrophysiological characteristics of the B cell. To assess the effects of these drugs, we examined the voltage responses, action potential amplitude, firing rate, light-elicited depolarization, and the resting membrane potential of groups of cells exposed to unpaired training in the three different bathing mediums. (It was not informative to examine the same characteristics in cells that had un- dergone paired training as we anticipated that these cells would respond differentially as a function of training and drug treatment. Although unpaired training could conceivably affect these characteristics of the $B$ cells, we have not observed such an effect relative to naive controls in prior work in which similar training parameters were used.) Relevant data for groups UP-ASW, UP-ANI:B, and UP-DANI:B are presented in Figure 4. The electrophysiological characteristics of the $\mathrm{B}$ cells were comparable across these groups, with none of the nominal differences approaching significance $[F \mathrm{~s}(1,179) \leqslant 0.70, \mathrm{NS}]$. This analysis suggests that neither ANI nor DANI had effects on general electrophysiological properties of these cells.

The effects of ANI or DANI incubation before or after training on the induction and persistence of neuronal enhancement are depicted in Figure 5, and representative voltage responses of four critical groups (UP-ASW, P-ASW, P-ANI:B, and P-ANI:A) are presented in Figure 6 . Looking first at the depolarizing voltage responses to a +0.8 - $\mathrm{nA}$ current injection, a two-factor ANOVA indicated a significant difference between the various groups $[F(9,179)=11.40, P<0.0001]$, and a significant group $\times$ retention interval interaction $[F(18,179)=$ 2.12, $P=0.01]$. B cells from nervous systems trained with paired light and rotation in normal ASW (group P-ASW) displayed a greater voltage response than did their unpaired counterparts (group UP-ASW) at both $5 \mathrm{~min}$ and $90 \mathrm{~min}$ after training $\left[F \mathrm{~s}(1,179) \geqslant 21.21, P_{\mathrm{s}}<0.001\right]$, indicative of the acquisition and 90-min retention of enhanced neuronal excitability following nine in vitro training trials. Of primary concern in this experiment were the effects of ANI and DANI administered before and during training relative to their effects when administered after training. Those cells exposed to paired training in the medium containing ANI (group P-ANI:B) exhibited elevated responses to current injection $5 \mathrm{~min}$ and $45 \mathrm{~min}$ after training relative to their respective unpaired control conditions $[F \mathrm{~s}(1,179) \geqslant 14.73, P \mathrm{~s} \leqslant 0.01]$. However, the voltage responses of these cells decreased during the retention interval such that 90 min after training the responses were significantly reduced relative to $5 \mathrm{~min}$ and $45 \mathrm{~min}$ after training $[F \mathrm{~s}(1,179) \geqslant 4.72, P \mathrm{~s}<0.05]$ and no longer differed from their unpaired control cells $[F(1,179)=$ $1.97, \mathrm{NS}]$. Thus, the administration of ANI before in vitro training resulted in a failure to sustain the training-induced increase in excitability for even

$$
\text { ,....... 圆" ...... }
$$


A

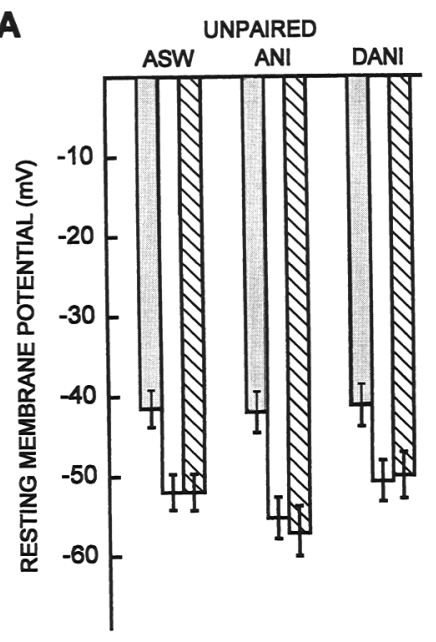

C

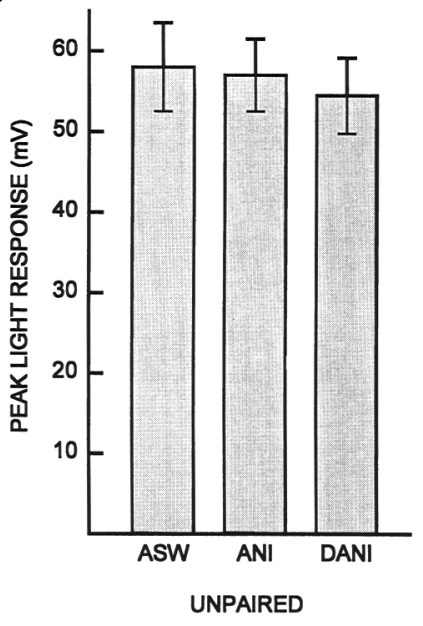

B
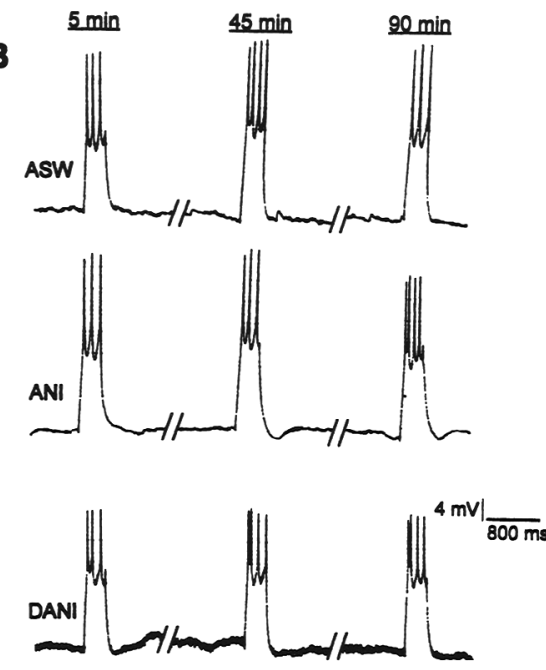

D
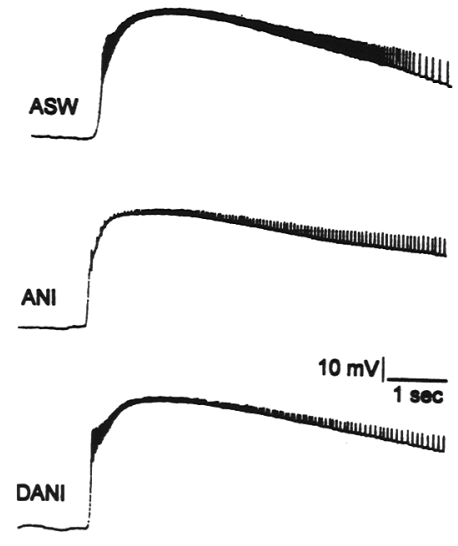

Light
Figure 4: Effect of protein synthesis inhibitors on electrophysiological characteristic of the B photoreceptors. Cells from nervous systems exposed to unpaired training following incubation in either ASW, ANI, or DANI are depicted, and no differences between groups were found on any measure. (A) The mean resting membrane potential recorded after 5 (shaded bars), 45 (open bars), or 90 (hatched bars) min of darkness following the last training event. Brackets indicate S.E.. (B) Representative voltage responses to $+0.8-n A$ current injections 5,45 , and $90 \mathrm{~min}$ after the final training event. The amplitude of the voltage response as well as the action potential amplitude and firing rate were comparable in all three groups. (C) The mean light-induced depolarization (peak) acquired at the 90-min retention interval. Brackets indicate S.E. (D) Representative voltage responses to light. The peak depolarization was used to compute the means that comprise $C$.
$90 \mathrm{~min}$. This pattern of results was not observed in either of the paired groups trained with DANI (present before and during or after conditioning) or in the group that was administered ANI after the completion of training. All of these groups displayed elevated voltage responses relative to their unpaired control groups $5 \mathrm{~min}$ after conditioning $[F s(1,179) \geqslant 23.6, P s<0.001]$, and none of them exhibited a decrease in this measure during the 90 min of retention $[F \mathrm{~s}(1,179) \leqslant 0.26$, NS $]$.

The data for evoked spike rates are summarized in the bottom panel of Figure 5. The relative magnitude of the increase in spike rate was somewhat smaller than was the increase in the voltage response to current injection, and in all conditions, spike rates tended to be more variable and to slow during the 90-min test interval. ANOVA indicated a significant difference between the various groups
$[F(9,179)=2.78, P<0.01]$. However, a significant group $\times$ retention interval interaction was not observed $[F(18,179)=0.35$, NS $]$, an effect that likely reflects the general tendency toward decreasing spike rates in all groups. Nevertheless, B cells from animals that had received paired training in ASW (P-ASW) exhibited elevated spike rates relative to unpaired animals (UP-ASW) on both the $5 \mathrm{~min}$ and 90 min retention tests $\left[F_{\mathbf{S}}(1,179) \geqslant 3.89, \quad P_{\mathrm{S}}<\right.$ 0.05]. Regarding the effects of ANI and DANI administered before or after training, relevant comparisons indicated a similar pattern of results to that suggested by the analysis of depolarizing voltage responses in the preceding paragraphs. However, the increased variability reflected in this measure complicates the statistical interpretation of the results. Of particular relevance is the effect of ANI when administered before training. Five min-

$$
\begin{array}{llllllllllllllll}
\hline & A & R & N & I & N & G & \mathbf{Q} & M & E & M & O & R & Y
\end{array}
$$


Figure 5: Effect of protein synthesis inhibition on short- and long-term enhancement of B-cell excitability. Isolated nervous systems were incubated in either ASW, ANI, or DANI. Training consisted of nine paired or nine unpaired trials in either ASW (P-ASW and UP-ASW), in ANI applied before training (P-ANI:B) or $5 \mathrm{~min}$ after the last trial (P-ANI:A), or in DANI applied before training (P-DANI:B) or $5 \mathrm{~min}$ after the last trial (P-DANI:A) (for a total of 10 groups). (Top) $B$-cell voltage responses were measured with +0.8 -nA current injections at 5 (shaded bars), 45 (open bars), and 90 (hatched bars) min after training. The depolarizing voltage responses of the $B$ cells were elevated at 5,45 , and $90 \mathrm{~min}$ after training in nervous systems trained with paired light and rotation and incubated in ANI after training and in DANI before or after training. The voltage response of $B$ cells receiving paired training in ANI was elevated at $5 \mathrm{~min}$, but at $90 \mathrm{~min}$ it had dissipated to control levels. All the unpaired control groups had relatively low depolarizing voltage responses at all retention intervals relative to the paired groups. Brackets indicate S.E. (Bottom) Evoked spike rates were measured with the same $+0.8-\mathrm{nA}$ current injections at 5, 45, and $90 \mathrm{~min}$ after training. The same general pattern of results was obtained, although the increase in spike

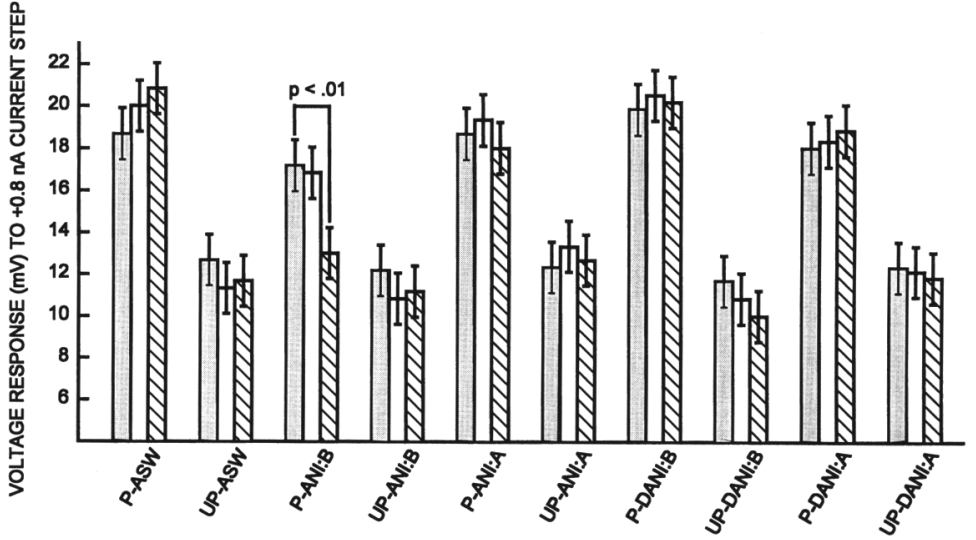
rate in $B$ cells trained in the presence of ANI did not reach significance relative to the unpaired control. Evoked spike rates of the paired ASW, paired ANI incubated after training, paired DANI before, and paired DANI after were elevated at 5, 45, and 90 min after training. Evoked spike rates of B cells trained in the presence of ANI exhibited a significant decrease during the 90-min retention interval. Brackets indicate S.E.

utes after paired training in the presence of ANI, group P-ANI:B exhibited a tendency toward an increase in evoked spike rate relative to its unpaired control (group UP-ANI:B), but this difference fell short of significance $[F(1,179)=1.97, \mathrm{NS}]$. Importantly though, paired training in the presence of ANI resulted in a significant decrease in evoked spike rate during the 90 -min retention interval $[F(1,179)=3.91, P<0.05]$. A significant decrease in spike rate during the retention interval was not observed in any other of the paired or unpaired conditions. Thus, as was the case with the enhanced depolarizing voltage responses, paired in vitro training in ANI resulted in a dissipation of excitability within $90 \mathrm{~min}$ of training relative to within 5 min of training. The results of our analysis of evoked spike rates must be treated cautiously, however, because cells trained in the presence of ANI failed to exhibit a significant increase in spike rate relative to their unpaired counterparts at the 5-min retention test. Although this later effect suggests the possibility that ANI reduced the initial level of conditioning, the failure to observe such an impairment in any other measure (behavioral or electrophysiological) in this series of experiments suggests that the failure to obtain statistical significance (despite the general tendency) on this single measure represents a statistical aberration.

\section{Discussion}

In the present experiments, we investigated the effects of number of training trials on the persistence of behaviorally assessed memory and on cellular correlates of memory (enhancement of neuronal excitability). Moreover, the dependence on protein synthesis for acquisition and persistence of memory and neuronal enhancement were also assessed. In experiment 1 , we determined that two pairings of light and rotation produced a short-

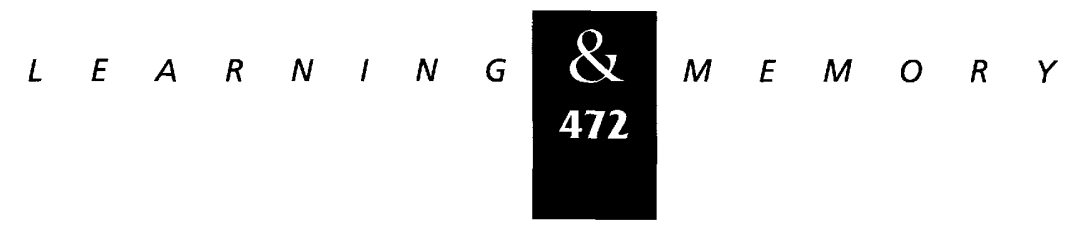




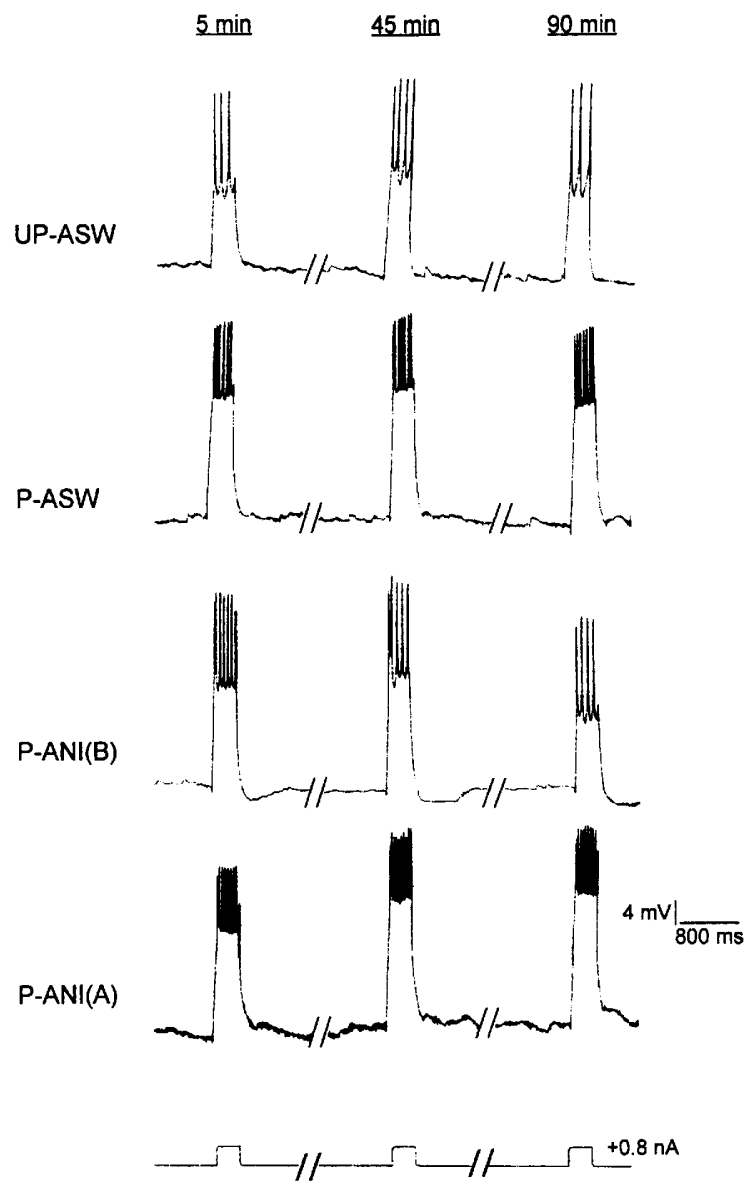

Figure 6: Representative voltage responses to $+0.8-n A$ current injection in cells that contributed to four of the groups illustrated in Fig. 5. Cells that underwent paired training in ASW (P-ASW) exhibited increased excitability (amplitude of voltage response and evoked spike rate) relative to the unpaired training in ASW (UP-ASW). A similar increase in excitability was observed in cells that received paired training following $A N I$ incubation ( $P$ ANI:B) or paired training followed by $\mathrm{ANI}$ incubation (P-ANI:A). Incubation in ANI during (but not after) training resulted in a decrease in excitability throughout the 90-min retention interval.

term (5-min) retention of a conditioned foot contraction indicative of memory, whereas nine pairings produced both a short-term memory as well as a more persistent (at least $90-\mathrm{min}$ ) retention of the conditioned response. In experiment 2 , it was determined that the persistent $(90-\mathrm{min})$ but not shortterm (5-min) expression of the conditioned response produced by nine paired trials was protein synthesis dependent, that is, incubation of animals in the protein synthesis inhibitor ANI before and during training produced a memory deficit on the 90-min retention test. In experiment 3, we found that although two in vitro pairings of light and rotation produced a transient enhancement of the excitability of the animal's B photoreceptor, more than two paired trials were necessary to promote persistent (90-min) enhancement. In experiment 4 , it was determined that the enhancement of Bcell excitability induced by nine training trials is protein synthesis dependent at $90 \mathrm{~min}$ but not 5 min after training. In total, these results indicate that the behavioral expression of a conditioned response as well as the underlying neuronal enhancement requires more than two training trials for retention intervals as short as $90 \mathrm{~min}$. Moreover, 90min retention is dependent on the initiation of protein synthesis at the time of (or shortly after) training. Thus, these results suggest that with some training parameters, the maintenance of a persistent memory trace requires the interaction of the extent of training with protein translation (cf. Crow and Forrester 1990), suggesting that there are at least two stages of memory in Hermissenda. The first stage, which underlies short-term memory, is not dependent on protein synthesis, whereas the second, more persistent form of memory requires such synthesis. Importantly though, in all of the experiments reported here, retention was not assessed at intervals longer than $90 \mathrm{~min}$, raising the possibility that an additional transcription or translation event at the time of training might underlie still longer retention.

Using an in vitro training procedure in which light was paired with application of the facilitatory transmitter 5-HT to the exposed nervous system of Hermissenda, Crow and Forrester (1990) reported results similar to those here. However, with their procedure, neuronal enhancement (indexed as an increase in amplitude of light-induced generator potentials) persisted following a single pairing. We cannot determine whether the in vitro training procedure used by Crow and Forrester is simply more efficacious than that used in the present studies or whether it accesses a different underlying mechanism. In support of the former possibility, it has been suggested that 5-HT and presynaptic stimulation (as used here) stimulate a similar class of postsynaptic neurochemical cascades (e.g., Rogers and Matzel 1995). In addition, it should be noted that Crow and Forrester administered a 5min training trial, raising the possibility that the total exposure to the training stimuli, not necessarily the number of trials, may be critical for the induction of the persistent form of memory. Relatedly, in Aplysia a single in vitro exposure of gill

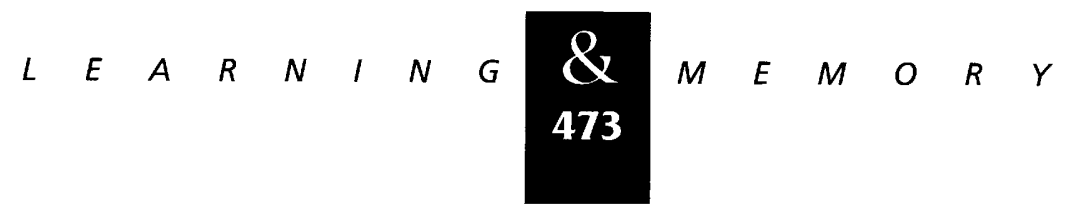


sensory neurons to 5-HT produces short-term nonassociative facilitation of excitatory synaptic transmission, whereas 10 or 15 such exposures produce a long-term facilitation that is dependent on protein synthesis and the transcription factors CREB1 and CREB2 (Montarolo et al. 1986; Alberini et al. 1994; Bartsch et al. 1995; Bailey et al. 1997; D. Michael, K.C. Martin, R. Seger, and E.R. Kandel, unpubl.). However, associative conditioning procedures have been established in which conditioned responding was evident $24 \mathrm{hr}$ after a single conditioning trial in Aplysia using a behavioral paradigm that is at least partly dependent on the same sensory-motor integration (e.g., Carew et al. 1983). Thus, these results, like those of Crow and Forrester (1990), suggest that there is not necessarily a unique feature of multiple trials that gives rise to the sustained, protein synthesis-depenent stage of memory but, rather, that single and multiple training trials represent points on a continuum, with the effectiveness of those trials dependent on the particular parameters of the training.

Even though the role of PKC in the induction and early maintenance of facilitation in the Hermissenda B cell is well-established, there have been somewhat contradictory claims about the role of PKC in the expression of long-lasting B-cell excitability enhancement. Crow and Forrester (1993b) reported that inhibition and down-regulation of $\mathrm{PKC}$ at the time of testing does not reverse the long-lasting enhancement of B-cell generator potentials. In contrast, Farley and Schuman (1991) reported that $\mathrm{PKC}$ inhibition at the time of testing does reverse long-lasting excitability enhancement in the B cells even days after training. Because the training procedures and the electrophysiological measurements were not comparable in these studies, future investigations will have to resolve the issue of whether long-lasting B-cell enhancement is kinase dependent in addition to its dependence on protein synthesis (although the two need not be mutually exclusive). In a recent Aplysia study, Emptage and Carew (1993) were capable of obtaining long-term facilitation without short-term facilitation. This implied that the cellular mechanisms responsible for short- and long-term facilitation in Aplysia are independent parallel systems, not necessarily requiring overlapping signals. This independence of short- and long-term memory processing has also been suggested to be the case in Hermissenda for the enhancement of the generator potential, because both inhibition and down-regu- lation of PKC at the time of training block the induction of the short-term enhancement but leave the long-term enhancement intact $24 \mathrm{hr}$ after conditioning (Crow and Forrester 1993b).

Interestingly, the protein synthesis-dependent stage of neuronal enhancement in Hermissenda displays a time course similar to protein synthesisdependent forms of hippocampal LTP in the rat (Nguyen et al. 1994; Huang et al. 1996). In both types of cellular plasticity, protein synthesis inhibition during and shortly after the induction protocol significantly disrupts the expression of the potentiation/enhancement within $90 \mathrm{~min}$ of induction, but protein synthesis inhibition initiated after induction is ineffective. This temporal equivalence suggests that both forms of persistent plasticity might share similar molecular mechanisms and supports the idea that the basic molecular pathways involved in memory maintenance have been selected and conserved throughout the evolution of memory systems.

In Hermissenda, little is known about the mechanisms underlying long-term storage of memories, other than the apparent dependence on protein synthesis. Although short-term enhancement of Hermissenda B cells does not appear to require the activation of a cAMP-dependent kinase (Matzel et al. 1990b), it is still possible that CREB may contribute to the maintenance phase of memory as it has been regularly found to do elsewhere (Tully et al. 1994; Bartsch et al. 1995; DeZazzo and Tully 1995; Yin et al. 1995; Guzowski and McGaugh 1997). This possibility arises from recent observations that $\mathrm{CREB}$ can be activated independently of cAMP (e.g., via the MAP kinase and CaMKII pathways; Deisseroth et al. 1996; Xing et al. 1996; Martin et al. 1997). In Hermissenda, PKC has been shown to phosphorylate a $20-\mathrm{kD}$ monomeric $G$ protein homologous in some respects to v-Ras (Neary et al. 1981; Nelson et al. 1990). This Ras-related protein could subsequently activate Raf, MEK, and MAPK (Segal and Greenberg 1996). Thus, PKC's phosphorylation of Ras could underlie the $\mathrm{Ca}^{2+}$ and PLC-dependent activation of the RasMAP kinase pathway (Segal and Greenberg 1995, 1996). Moreover, PKC has been shown to directly activate the protein tyrosine kinase PYK2, which has been implicated in the activation of MAP kinase (Lev et al. 1995). Thus, it is possible that PKC activation in Hermissenda B cells translocates MAP kinases to the nucleus, where they are believed to induce CREB phosphorylation (Xing et al. 1996; Martin et al. 1997). Interestingly, a combinatorial

$$
\text { n...... }
$$


threshold (Michael et al. 1998), reached only following the coincident graded translocation of MAP kinase and other signals to the nucleus, might explain the advantage that multiple trials have in inducing the protein synthesis-dependent consolidation of memory. This would parallel the incremental translocation of PKC to the B-cell membrane, which is thought to underlie the learning acquisition curve in Hermissenda (Muzzio et al. 1997).

In addition to the PKC-dependent mechanisms described above, it is possible that although $\mathrm{PKC}$ is required for the initial stages of facilitation in $\mathrm{Her}$ missenda B cells, an independent cAMP-dependent phosphorylation and/or transcription event may be required for the protein synthesis-dependent stages of facilitation (memory) in Hermissenda (for related data, see Crow and Forrester 1993a). Similar parallel mechanisms appear to play a role in the expression of multiple phases of some forms of hippocampal LTP (Nguyen and Kandel 1996; Abel et al. 1997) and may contribute to memory storage in Aplysia (for review, see Alberini et al. 1995). At present, none of the available data allows us to distinguish between these possibilities with regard to long-term neuronal facilitation and memory in Hermissenda. The present work provides a framework for exploring the role of these molecular pathways in the storage of longterm memory in Hermissenda.

\section{Acknowledgments}

This work was supported by the U.S. Public Health Service National Institute of Mental Health (grants MH48387 and MH52314), the Charles and Johanna Busch Memorial Fund, and a Hoechst-Celanese Young Faculty Award (all to L.D.M.) and an American Psychological Association predoctoral minority fellowship to I.A.M. We thank Linda Farina for her assistance.

The publication costs of this article were defrayed in part by payment of page charges. This article must therefore be hereby marked "advertisement" in accordance with 18 USC section 1734 solely to indicate this fact.

\section{References}

Abel, T., P.V. Nguyen, M. Barad, T.A.S. Deuel, E.R. Kandel, and R. Bourtchouladze. 1997. Genetic demonstration of a role for PKA in the late phase of LTP and in hippocampus-based long-term memory. Cell 88: 615-626.

Abraham, W.C., M. Dragunow, and W.P. Tate. 1992. The role of immediate early genes in the stabilization of long-term potentiation. Mol. Neurobiol. 5: 297-314.

Alberini, C.M., M. Ghirardi, R. Metz, and E.R. Kandel. 1994.
$\mathrm{C} / \mathrm{EBP}$ is an immediate-early gene required for the consolidation of long-term facilitation in Aplysia. Cell 76: 1099-1114.

Alberini, C.M., M. Ghirardi, Y.-Y. Huang, P.V. Nguyen, and E.R. Kandel. 1995. A molecular switch for the consolidation of long-term memory: cAMP-inducible gene expression. Ann. N.Y. Acad. Sci. 758: 261-286.

Alkon, D.L. 1984. Calcium-mediated reduction of ionic currents: A biophysical memory trace. Science 226: 1037-1045.

Alkon, D.L., M. Sakakibara, R. Forman, J. Harrigan, I. Lederhendler, and J. Farley. 1985. Reduction of two voltage-dependent $\mathrm{K}^{+}$currents mediates retention of a learned association. Behav. Neural Biol. 44: 278-300.

Alkon, D.L., S. Naito, M. Kubota, C. Chen, B. Bank, J. Smallwood, P. Gallant, and H. Rasmussen. 1988. Regulation of Hermissenda $\mathrm{K}+$ channels by cytoplasmic and membrane-associated C-kinase. J. Neurochem. 51: 903-917.

Alkon, D.L., H. Ikeno, J. Dworkin, D.L. McPhie, J.L. Olds, I. Lederhendler, L. Matzel, B.G. Schreurs, A. Kuzirian, C. Collin, and E. Yamoah. 1990. Contraction of neuronal branching volume: An anatomic correlate of Pavlovian conditioning. Proc. Natl. Acad. Sci. 87: 1611-1614.

Bailey, C.H., P. Montarolo, M. Chen, E.R. Kandel, and S. Schacher. 1992. Inhibitors of protein and RNA synthesis block structural changes that accompany long-term heterosynaptic plasticity in Aplysia. Neuron 9: 749-758.

Bailey, C.H., B.K. Kaang, M. Chen, K.C. Martin, C.S. Lim, A. Casadio, and E.R. Kandel. 1997. Mutation in the phosphorylation sites of MAP kinase blocks learning-related internalization of apCAM in Aplysia sensory neurons. Neuron 18: $913-924$.

Bartsch, D., M. Ghirardi, P.A. Skehel, K.A. Karl, S.P. Herder, M. Chen, C.H. Bailey, and E.R. Kandel. 1995. Aplysia CREB2 represses long-term facilitation: Relief of repression converts transient facilitation into long-term functional and structural change. Cell 83: 979-992.

Bourtchuladze, R., B. Frenguelli, J. Blendy, D. Cioffi, G. Schutz, and A.J. Silva. 1994. Deficient long-term memory in mice with a targeted mutation of the CAMP-responsive element-binding protein. Cell 79: 59-68.

Carew, T.J. 1996. Molecular enhancement of memory formation. Neuron 16: 5-8.

Carew, T. J., R.D. Hawkins, and E.R. Kandel. 1983. Differential classical conditioning of a defensive withdrawal reflex in Aplysia californica. Science 219: 397-400.

Castellucci, V.H., H. Blumenfeld, P. Goelet, and E.R. Kandel. 1989. Inhibitor of protein synthesis blocks long-term behavioral sensitization in the isolated gill-withdrawal reflex of Aplysia. J. Neurobiol. 20: 1-9.

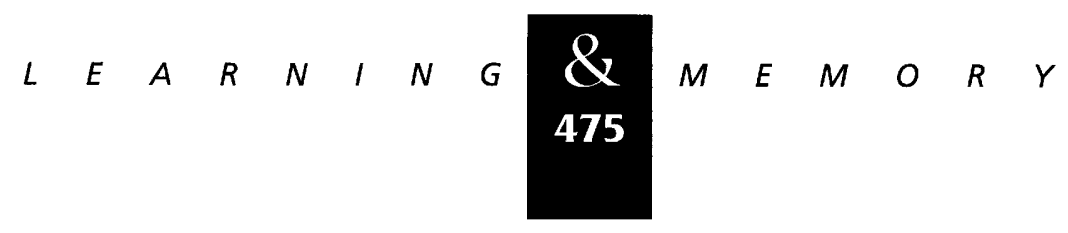


Ramirez et al.

Crow, T.J., and D.L. Alkon. 1978. Retention of an associative behavioral change in Hermissenda. Science 201: 1239-1241.

Crow, T. and J. Forrester. 1990. Inhibition of protein synthesis blocks long-term enhancement of generator potentials produced by one-trial in vivo conditioning in Hermissenda. Proc. Natl. Acad. Sci. 87: 4490-4494.

1993a. Protein kinase inhibitors do not block the expression of established enhancement in identified Hermissenda B-photoreceptors. Brain Res. 613: 61-66.

1993b. Down-regulation of protein kinase $C$ and kinase inhibitors dissociate short- and long-term enhancement produced by one-trial conditioning of Hermissenda. J. Neurophysiol. 69: 636-641.

Crow, T., V. Siddiqi, Q. Zhu, and J.T. Neary. 1996. Time-dependent increase in protein phosphorylation following one-trial enhancement in Hermissenda. J. Neurochem. 66: 1736-1741.

Davis, H.P. and L.R. Squire. 1984. Protein synthesis and memory: A review. Psychol. Bull. 96: 518-559.

Deisseroth, K., H. Bito, and R.W. Tsien. 1996. Signaling from synapse to nucleus: Postsynaptic CREB phosphorylation during multiple forms of hippocanpal synaptic plasticity. Neuron 16: 89-101.

DeZazzo, J. and T. Tully. 1995. Dissection of memory formation: From behavioral pharmacology to molecular genetics. Trends Neurosci. 18: 212-218.

Eichenbaum, H. 1996. Learning from LTP: A comment on recent attempts to identify cellular and molecular mechanisms of memory. Learn. \& Mem. 3: 61-73.

Emptage, N.J. and T.J. Carew. 1993. Long-term synaptic facilitation in the absence of short-term facilitation in Aplysia neurons. Science 262: 253-256.

Falk-Vairant, J. and T. Crow. 1993. Intracellular injections of BAPTA block induction of enhancement in Hermissenda type B photoreceptors. Neurosci. Lett. 147: 45-48.

Farley, J. 1988. Associative training results in persistent reductions in a calcium-activated potassium current in Hermissenda Type B photoreceptors. Behav. Neurosci. 102: 784-802.

Farley, J. and E. Schuman. 1991. Protein kinase C inhibitors prevent induction and continued expression of cell memory in Hermissenda type B photoreceptors. Proc. Natl. Acad. Sci. 88: 2016-2020.

Farley, J., W.G. Richards, L.J. Ling, E. Liman, and D.L. Alkon. 1983. Membrane changes in a single photoreceptor cause associative learning in Hermissenda. Science 221: 1201-1203.

Flexner, J.B., L.B. Flexner, and E. Stellar. 1963. Memory in mice as affected by intracerebral puromycin. Science 141: $57-59$.

Frank, D.A. and M.E. Greenberg. 1994. CREB: A mediator of long-term memory from mollusks to mammals. Cell 79: 5-8.

Frey, U. and R.G.M. Morris. 1997. Synaptic tagging and long-term potentiation. Nature 385: 533-536.

Guzowski, J.F. and J.L. McGaugh. 1997. Antisense oligodeoxynucleotide-mediated disruption of hippocampal cAMP response element binding protein levels impairs consolidation of memory for water maze training. Proc. Natl. Acad. Sci. 94: 2693-2698.

Huang, Y.-Y., X.-C. Li, and E.R. Kandel. 1994. cAMP contributes to mossy fiber LTP by initiating both a covalently mediated early phase and macromolecular synthesis-dependent late phase. Cell 79: 69-79.

Huang, Y.-Y., Nguyen, P.V., T. Abel, and E.R. Kandel. 1996. Long-lasting forms of synaptic potentiation in the mammalian hippocampus. Learn. \& Mem. 3: 74-85.

Kaang, B.-K, E.R. Kandel, and S.G.N. Grant. 1993. Activation of cAMP-responsive genes by stimuli that produce long-term facilitation in Aplysia sensory neurons. Neuron 10: 427-435.

Kaczmarek, L. 1992. Expression of c-fos and other genes encoding transcription factors in long-term potentiation. Behav. Neural Biol. 57: 263-266.

Katz, J.J. and W.C. Halstead. 1950. Protein organization and mental function. Comp. Psychol. Monographs 20: 1-38.

Lederhendler, I. S. Gart, and D.L. Alkon. 1986. Classical conditioning of Hermissenda: Origin of a new response. J. Neurosci. 6: 1325-1331.

Lev, S., H. Moreno, R. Martinez, P. Canoll, E. Peles, J.M. Musacchio, G.D. Plowman, B. Rudy, and J. Schlessinger. 1995. Protein tyrosine kinase PYK2 involved in $\mathrm{Ca}^{2+}$-induced regulation of ion channel and MAP kinase functions. Nature 376: 737-745.

Linden, D.J. 1996. A protein synthesis-dependent late phase of cerebellar long-term depression. Neuron 17: 483-490.

Lisman, J. 1994. The CaM kinase II hypothesis for the storage of synaptic memory. Trends Neurosci. 17: 406-412.

1995. What does the nucleus know about memories?

J. NIH Res. 7: 43-46.

Llinas, R., E.J. Lang, and J.P. Welsh. 1997. The cerebellum, LTD, and memory: Alternative views. Learn. \& Mem. 3: $445-455$.

Martin, K.C., D. Michael, J.C. Rose, M. Barad, A. Casadio, H. Zhu, and E.R. Kandel. 1997. MAP kinase translocates into the nucleus of the presynaptic cell and is required for long-term facilitation in Aplysia. Neuron 18: 899-912.

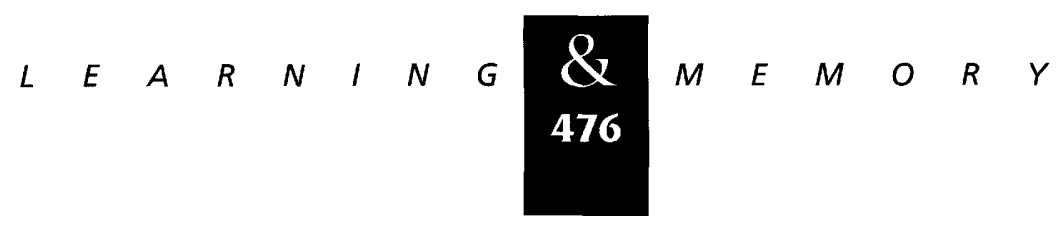


Matzel, L.D. and R. Rogers. 1993. Postsynaptic calcium, but not cumulative depolarization, is necessary for the induction of associative plasticity in Hermissenda. J. Neurosci. 13: 5029-5040.

Matzel, L.D., I.I. Lederhendler, and D.L. Alkon. 1990a. Regulation of short-term associative memory by calcium-dependent protein kinase. J. Neurosci. 10: $2300-2307$.

Matzel, L.D., B. Schreurs, and D.L. Alkon. 1990b. Pavlovian conditioning of distinct components of Hermissenda's responses to rotation. Behav. Neural Biol. 54: 131-145.

Matzel, L.D., C. Collin, and D.L. Alkon. 1992. Biophysical and behavioral correlates of memory storage, degradation, and reactivation. Behav. Neuro. 106: 954-963.

Matzel, L.D., I.A. Muzzio, and A.C. Talk. 1996. Variations in learning reflect individual differences in sensory function and synaptic integration. Behav. Neurosci. 110: 1084-1095.

Matzel, L.D., B. Schreurs, and D.L. Alkon. 1990b. Pavlovian conditioning of distinct components of Hermissenda's responses to rotation. Behav. Neural Biol. 54: 131-145.

Michael, D., K.C. Martin, R. Seger, M.M. Ning, R. Baston, and E.R. Kandel. 1998. Repeated pulses of serotonin required for long-term facilitation activate mitogen-activated protein kinase in sensory neurons of Aplysia. Proc. Natl. Acad. Sci. 95: 1864-1869.

Montarolo, P.G., P. Goelet, V.F. Castellucci, J. Morgan, E.R. Kandel, and S. Schacher. 1986. A critical period for macromolecular synthesis in long-term heterosynaptic facilitation in Aplysia. Science 234: 1249-1254.

Muzzio, I.A., A.C. Talk, and L.D. Matzel. 1997. Incremental translocation of protein kinase $\mathrm{C}$ underlies the acquisition "curve" during the formation of an associative memory. Behav. Neurosci. 111: 739-753.

Neary, I.T., T. Crow, and D.L. Alkon. 1981. Change in a specific phosphoprotein band following associative learning in Hermissenda. Nature 293: 658-660.

Nelson, T.J. and D.L. Alkon. 1988. Prolonged RNA changes in the Hermissenda eye induced by classical conditioning. Proc. Natl. Acad. Sci. 85: 7800-7804.

Nelson, T.J., C. Collin, and D.L. Alkon. 1990. Isolation of a G-protein that is modified by learning and reduces potassium currents in Hermissenda. Science 247: 1479-1483.

Nguyen, P.V. and E.R. Kandel. 1996. A macromolecular synthesis-dependent phase of long-term potentiation requiring CAMP in the medial perforant pathway of rat hippocampal slices. J. Neurosci. 16: 3189-3198.

Nguyen, P.V., T. Abel, and E.R. Kandel. 1994. Requirement of a critical period of transcription for induction of a late phase of LTP. Science 265: 1104-1107.
Osten, P., L. Valsamis, A. Harris, and T.D. Sacktor. 1996. Protein synthesis-dependent formation of protein kinase $M \zeta$ in long-term potentiation. J. Neurosci. 15: 2444-2451.

Pedreira, M.E., B. Dimant, and H. Maldonado. 1996. Inhibitors of protein and RNA synthesis block context memory and long-term habituation in the crab Chasmagnathus. Pharm. Biochem. Behav. 54: 611-617.

Rogers, R.F. and L.D. Matzel. 1995. G-protein mediated responses to localized serotonin application in an invertebrate photoreceptor. NeuroReport 6: 2161-2165.

Segal, R.A. and M.E. Greenberg. 1996. Intracellular signalling pathways activated by neurotrophic factors. Annu. Rev. Neurosci. 19: 463-489.

Shors, T.J. and L.D. Matzel. 1997. Long-term potentiation:What's learning got to do with it? Behav. Brain Sci. 20: 597-655.

Spatz, H.P. 1995. Posttranslational modification of protein kinase A. The link between short-term and long-term memory. Behav. Brain Res. 66: 79-84.

Stevens, C.F. 1994. CREB and memory consolidation. Neuron 13: 769-770.

Talk, A.C., I.A. Muzzio, and L.D. Matzel. 1997. Phospholipases and arachidonic acid contribute independently to sensory transduction and associative neuronal facilitation in Hermissenda type B photoreceptors. Brain Res. 751: 196-205.

Tully, T. 1997. Regulation of gene expression and its role in long-term memory and synaptic plasticity. Proc. Natl. Acad. Sci. 94: 4239-4241.

Tully, T., T. Preat, S.C. Boynton, and M. Del Vecchio. 1994 Genetic dissection of consolidated memory in Drosophila. Cell 79: 35-47.

West, A., E. Barnes, and D.L. Alkon. 1982. Primary changes of voltage responses during retention of associative learning. J. Neurophysiol. 48: 1243-1255.

Xing, J., D.D. Ginty, and M.E. Greenberg. 1996. Coupling of the RAS-MAPK pathway to gene activation by RSK2, a growth factor regulated CREB kinase. Science 273: 959-963.

Yin, J.C.P., J.S. Wallach, M. Del Vecchio, E.L. Wilder, H. Zhou, W.G. Quinn, and T. Tully. 1994. Induction of a dominant negative CREB transgene specifically blocks long-term memory in Drosophila. Cell 79: 49-58.

Yin, J.C.P., M. Del Vecchio, H. Zhou, and T. Tully. 1995. CREB as a memory modulator: Induced expression of a dCREB2 activator isoform enhances long-term memory in Drosophila. Cel/ 81: 107-115.

Received August 11, 1997; accepted in revised form March 10, 1998.

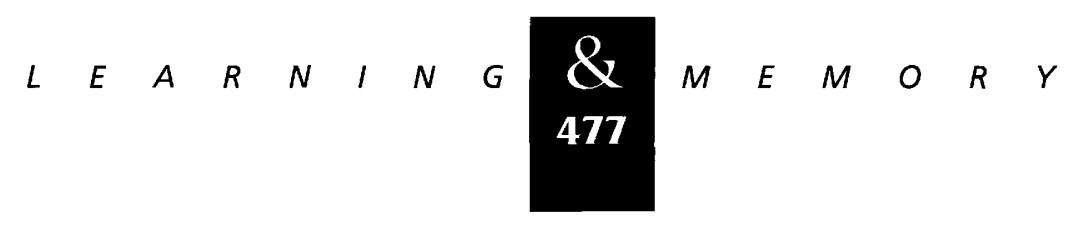




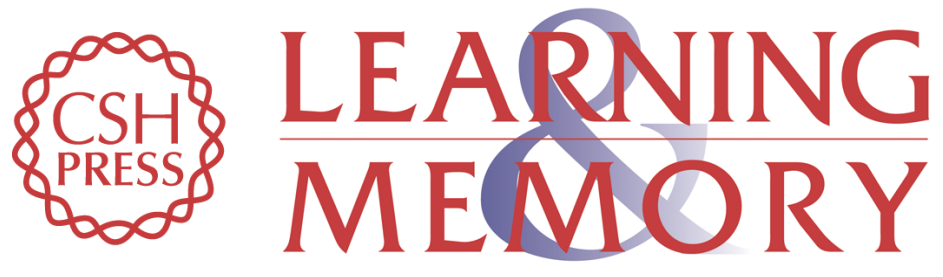

Protein synthesis-dependent memory and neuronal enhancement in Hermissenda are contingent on parameters of training and retention.

R R Ramirez, C C Gandhi, I A Muzzio, et al.

Learn. Mem. 1998, 4:

Access the most recent version at doi:10.1101//m.4.6.462

References This article cites 73 articles, 24 of which can be accessed free at: http://learnmem.cshlp.org/content/4/6/462.full.html\#ref-list-1

License

Email Alerting

Receive free email alerts when new articles cite this article - sign up in the box at the Service top right corner of the article or click here. 